\title{
Modulatory effects of gonadotrophins and insulin-like growth factor on the secretion of inhibin A and progesterone by granulosa cells from chicken preovulatory (F1-F3) follicles
}

\author{
T. M. Lovell ${ }^{1}$, R. T. Gladwell ${ }^{1}$, N. P. Groome ${ }^{2}$ and P. G. Knight ${ }^{1 *}$ \\ ${ }^{1}$ School of Animal and Microbial Sciences, University of Reading, Whiteknights, Reading \\ RG6 6AJ, UK; and ${ }^{2}$ School of Biological and Molecular Sciences, Oxford Brookes University, \\ Oxford OX3 OBP, UK
}

\begin{abstract}
The aim of this study was to compare the actions and interactions of gonadotrophins ( $\mathrm{LH}$ and $\mathrm{FSH}$ ) and an analogue of insulin-like growth factor I (LR3-IGF-I) on the secretion of inhibin $A$, inhibin $B$ and progesterone by cultured chicken granulosa cells derived from the three largest (F1-F3) follicles of the preovulatory hierarchy. Treatment with LH or FSH promoted marked dose$(P<0.0001)$ and time- $(P<0.0001)$ dependent increases in both inhibin $A$ and progesterone secretion, with the magnitude of response $(<15$-fold compared with basal) increasing over time in culture. Concentrations of inhibin B were below the detection limit in all samples. Initially, F1 cells were more LH-responsive than were $\mathrm{F} 3$ cells in terms of progesterone secretion $(P<0.02)$ but this difference between follicles decreased over time in culture. In contrast, LH-induced inhibin A secretion tended to be highest from F3 cells, although this was not significant. Cells from F3 follicles were consistently more FSHresponsive than $\mathrm{F} 1$ cells in terms of both progesterone $(P<0.01)$ and inhibin A $(P<0.02)$ secretion. Initially, F1 cells were more responsive to LR3-IGF-I than were $\mathrm{F} 3$ cells
\end{abstract}

in terms of progesterone secretion $(P<0.001)$ but were less responsive in terms of inhibin A secretion $(P<0.001)$. Again, these inter-follicle differences decreased over time in culture (not significant on day 3 of treatment). Cotreatment experiments showed that LR3-IGF-I enhanced both LH- and FSH-induced secretion of inhibin $A$ and progesterone in a time- $(P<0.001)$ and follicle- $(P<0.001)$ dependent way. Initially, F1 cells showed highest LR3-IGFI enhancement of LH-induced inhibin A and progesterone secretion; in contrast, F3 cells showed the highest LR3IGF-1 enhancement of FSH-induced inhibin A and progesterone secretion. These inter-follicle differences persisted over time in the case of $\mathrm{FSH}$-induced hormone responses but not in the case of $\mathrm{LH}$-induced responses, even though the relative degree of LR3-IGF-I enhancement increased markedly over time. Collectively, these data support a positive role for IGF-I, presumably of thecal origin, as an amplifier of gonadotrophin action on granulosa cell inhibin $A$ and progesterone production by preovulatory chicken follicles.

\section{Introduction}

The functional left ovary of a domestic hen typically contains between five and nine yolk-filled preovulatory follicles arranged in a distinct size hierarchy. The largest follicle, designated F1 (approximately $35 \mathrm{~mm}$ in diameter), is first to ovulate, followed by the second largest follicle (F2) approximately 24-26 h later and this continues down the hierarchy. This ordered arrangement of preovulatory follicles makes the hen an excellent model for the study of factors regulating the later stages of folliculogenesis. The production of steroids by granulosa and theca (interna and externa) layers of hen hierarchical follicles has been studied extensively. Granulosa tissue of F1-F4 preovulatory follicles contains significantly more progesterone than does

*Correspondence

Email:p.g.knight@reading.ac.uk theca tissue (Etches and Duke, 1984; Kato et al., 1995). Conversely, thecal tissue contains significantly more testosterone and oestradiol (Kato et al., 1995). A three-cell model of steroidogenesis in avian follicles that takes the differential steroidogenic activities of the theca externa, theca interna and granulosa cell layers into account has been proposed by Porter et al. (1989).

There is increasing evidence, mainly from mammalian species, to support local autocrine/paracrine roles of various growth factors, including insulin-like growth factors (IGF-I and II), transforming growth factor $\beta$ (TGF $\beta$ ) superfamily members (for example, inhibins and activins) and epidermal growth factor (EGF)-related peptides (including TGF $\alpha$ ) in modulation of ovarian follicle function and steroidogenesis (Adashi et al., 1992; Knight and Glister, 2001). For example, IGF-I, activin A and EGF/TGF $\alpha$ are expressed in rat follicles: IGF-I and activin A augment FSHdependent processes, such as inhibin production and 
steroidogenesis, in cultured rat granulosa cells (Adashi et al., 1992; Xiao et al., 1992), whereas EGF/TGF $\alpha$ suppresses inhibin production and steroidogenesis (Hsueh et al., 1981; Glister et al., 2001). Chicken granulosa cells express receptors for IGF-I (Roberts et al., 1994) and EGF/TGF $\alpha$ (Onagbesan et al., 1994) but there have been relatively few studies to investigate the potential actions of such growth factors on granulosa cell proliferation and steroidogenesis in birds (Peddie et al., 1994; Onagbesan and Peddie, 1995; Onagbesan et al., 1999a,b, 2000).

Likewise, there have been only a few attempts to study the factors regulating the production of inhibin-related peptides from avian granulosa cells, despite their wellestablished roles in mammalian species. Vanmontfort et al. (1992) cultured granulosa cells from hen preovulatory (F1-F4) follicles and found that secretion of immunoreactive inhibin was highest from $\mathrm{F} 4$ follicles and lowest in F1 follicles. Secretion of immunoreactive inhibin was stimulated by both LH and FSH. However, the inhibin radioimmunoassay used in the study of Vanmontfort et al. (1992) has limited specificity and crossreacts extensively $(100 \%)$ with free inhibin $\alpha$-subunit forms. The high concentrations of inhibin $\alpha$-subunit present in hen plasma (Lovell et al., 2000a, 2001), cockerel plasma (Lovell et al., 2000b) and F1 preovulatory follicle granulosa cell extract (Lovell et al., 1998) signal the need for caution in interpreting earlier findings based on the use of 'first generation' inhibin radioimmunoassays lacking specificity for the $\alpha \beta$ dimeric molecule. In chicken preovulatory follicles, inhibin A, like progesterone, is produced selectively by granulosa rather than theca cells (Lovell et al., 2000c, 2001), with maximal concentrations in the F1 granulosa layer (Lovell et al., 1998, 2000a, 2001), which also shows maximal expression of inhibin/activin $\beta_{\mathrm{A}}$ subunit mRNA (Chen and Johnson, 1996a; Safi et al., 1998). In contrast, theca layers of F1-F4 follicles contain significantly more activin A than do corresponding granulosa layers (Lovell et al., 1998, 2000c, 2001).

The aims of the present study were to use a hen granulosa cell culture system in combination with highly specific inhibin A and inhibin B immunoassays to: (i) compare the effects of $\mathrm{LH}$ and $\mathrm{FSH}$ on the secretion of dimeric inhibins and progesterone by granulosa cells from F1, F2 and F3 preovulatory follicles; and (ii) investigate the effects of an IGF-I analogue on basal, LH-induced and FSH-induced secretion of dimeric inhibins and progesterone.

\section{Materials and Methods}

\section{Experimental animals}

Laying hens (ISA brown) towards the end of their first year of laying were caged individually and maintained under a standard long-day photoschedule of $16 \mathrm{~h} \mathrm{light:8 \textrm {h }}$ dark, at an ambient temperature of $21-23^{\circ} \mathrm{C}$. Food and water were freely available. Daily oviposition times were recorded and used to predict the timing of oviposition.

\section{Isolation of granulosa cells}

Hens ( $n=5-6$ per culture experiment) were killed by cervical dislocation approximately $4 \mathrm{~h}$ after ovulation of a mid-sequence egg. The three largest preovulatory follicles (F1-F3) of the ovarian hierarchy were removed and placed immediately in sterile Hank's balanced salt solution (HBSS; Gibco-BRL, Uxbridge). Granulosa and theca layers were separated in sterile conditions in a laminar flow cabinet (Gilbert et al., 1977).

In brief, granulosa layers derived from a given hierarchical follicle position in different hens were combined (creating separate F1, F2 and F3 pools) and transferred to digestion medium (medium 199 with 25 mmol Hepes $\mathrm{I}^{-1}$, $0.1 \%(\mathrm{w} / \mathrm{v})$ collagenase (type IV), $0.01 \%(\mathrm{v} / \mathrm{v})$ trypsin inhibitor (type I-S), 0.3\% (w/v) BSA (fraction V), $0.01 \%(\mathrm{v} / \mathrm{v}$ ) L-glutamine and $1 \%(\mathrm{v} / \mathrm{v})$ antibiotic stock solution $(5000 \mathrm{U}$ penicillin $\mathrm{ml}^{-1}$ and $5000 \mathrm{U}$ streptomycin $\mathrm{ml}^{-1}$; all from Sigma UK Ltd, Poole). Approximately $2 \mathrm{ml}$ of digestion medium was used per $500 \mathrm{mg}$ tissue. Tissues were aspirated 30 times with a sterile Pasteur pipette (Alpha Laboratories Ltd, Eastleigh), incubated for $30 \mathrm{~min}$ at $37^{\circ} \mathrm{C}$ and then reaspirated 30 times. Cells were retrieved by centrifugation at $400 \mathrm{~g}$ for $8 \mathrm{~min}$ at room temperature. The supernatant was decanted; the pellet was resuspended in $10 \mathrm{ml}$ fresh incubation medium (medium 199 with 25 mmol Hepes $\mathrm{I}^{-1}, 0.01 \%$ $(\mathrm{v} / \mathrm{v})$ L-glutamine and $1 \%(\mathrm{v} / \mathrm{v})$ antibiotic solution) and centrifuged at $400 \mathrm{~g}$ for $8 \mathrm{~min}$ at room temperature. The supernatant was decanted and the pellet was dispersed in $2 \mathrm{ml}$ fresh plating medium (incubation medium containing $2 \%(\mathrm{v} / \mathrm{v})$ charcoal-stripped fetal calf serum; Sigma UK Ltd). The number of viable cells was estimated by trypan blue exclusion (Sigma UK Ltd). Isolated granulosa cells were diluted in plating medium and divided into aliquots in 24well plates (Falcon 3047; Becton Dickinson Labware, Franklin Lakes, NJ) at $3 \times 10^{5}$ viable cells per well. The cells were maintained for $24 \mathrm{~h}$ at $39^{\circ} \mathrm{C}$. Unattached cells were aspirated off and the attached cells were washed three times with $1 \mathrm{ml}$ serum-free incubation medium. All further incubations were done under serum-free conditions. Incubation buffer $(1 \mathrm{ml})$ and test treatments were added to appropriated wells. The cells were incubated for $24 \mathrm{~h}$ and conditioned media were aspirated and stored at $-20^{\circ} \mathrm{C}$. The media were replenished every $24 \mathrm{~h}$ and the test treatments were also added at these times. At termination of culture, the media were removed and the monolayers were washed three times with PBS (Oxoid Ltd, Basingstoke). The plated cells were sonicated in PBS containing $1 \%(\mathrm{w} / \mathrm{v})$ BSA (protease free), $1 \%(\mathrm{v} / \mathrm{v})$ Triton-X100 (Sigma UK Ltd) and $0.1 \%(\mathrm{w} / \mathrm{v})$ sodium azide (Fisher Scientific UK Ltd, Loughborough; $200 \mu \mathrm{l}$ per well), and the resultant suspension was stored at $-20^{\circ} \mathrm{C}$.

\section{Treatments}

All treatments were prepared as stock solutions: OLH (NIDDK-oLH-25) and oFSH (NIDDK-oFSH-19-SIAPH) were prepared at $10 \mu \mathrm{g} \mathrm{ml}^{-1}$ in HBSS containing $0.3 \%(\mathrm{v} / \mathrm{v}) \mathrm{BSA}$ 

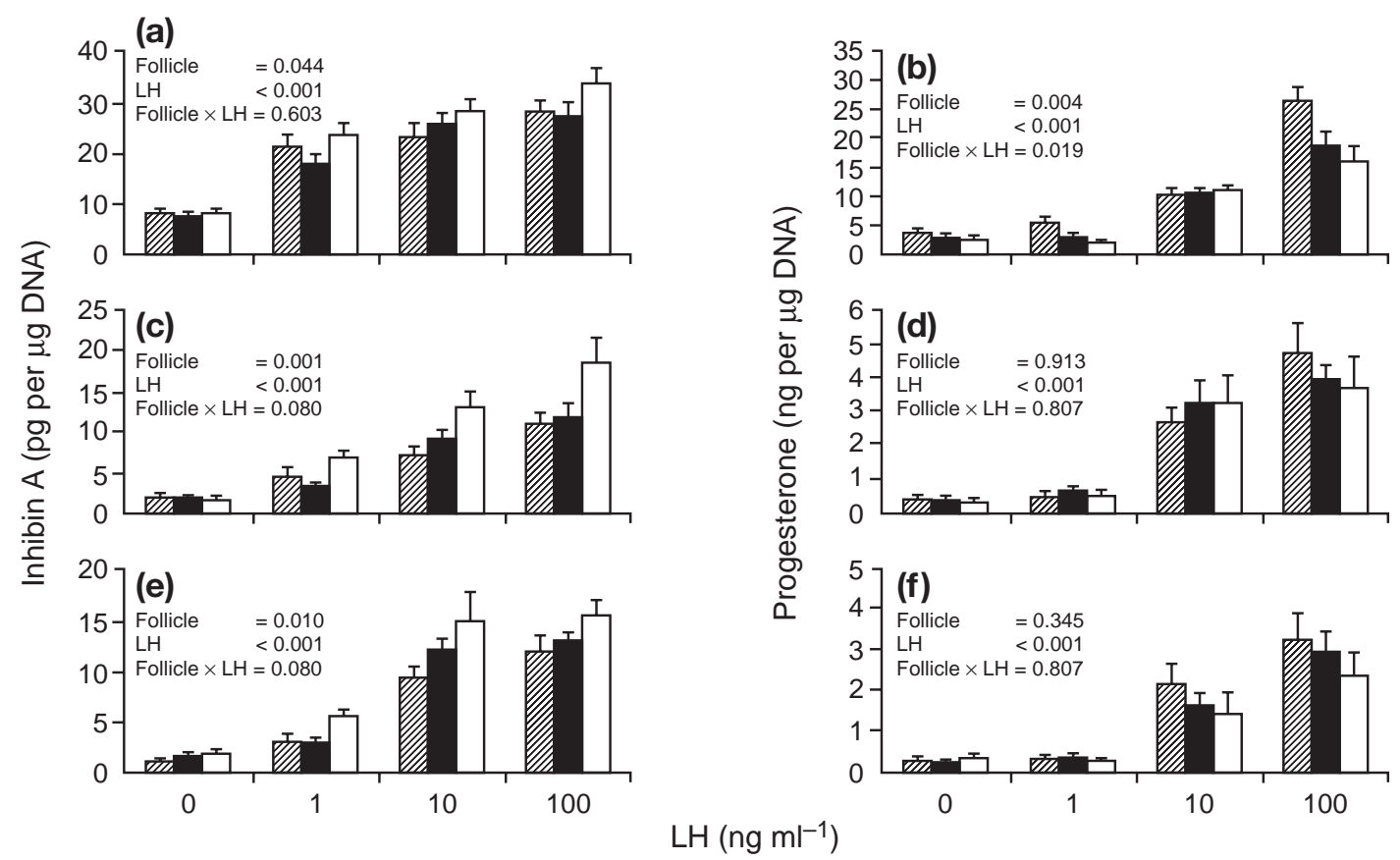

Fig. 1. Effect of $\mathrm{LH}$ on the secretion of $(\mathrm{a}, \mathrm{c}, \mathrm{e})$ inhibin $\mathrm{A}$ and $(\mathrm{b}, \mathrm{d}, \mathrm{f})$ progesterone by cultured hen granulosa cells derived from F1 $(\mathbb{Z}), F 2(\square)$ and F3 $(\square)$ preovulatory follicles. Data for three consecutive $24 \mathrm{~h}$ incubations are shown: (a,b): 24-48 h; (c,d) 48-72 h; and (e,f): 72-96 h. Values are mean \pm SEM ( $n=3$ replicate cultures). Results of ANOVA are indicated on each panel.

(fraction V); and long R3 IGF-I (LR3-IGF-I; Sigma UK Ltd) was prepared at $0.1 \mathrm{mg} \mathrm{ml}^{-1}$. Before culture, the treatments were diluted in HBSS containing $0.3 \%(\mathrm{v} / \mathrm{v})$ BSA to a $\times 40$ treatment concentration and filter-sterilized using a $0.2 \mu \mathrm{m}$ Millipore filter (FlowPore D; ICN Biomedicals Ltd, Basingstoke). Treatments were added to respective wells to give final concentrations of 1,10 and $100 \mathrm{ng} \mathrm{ml}^{-1}$ for oLH and oFSH, and 1 and $10 \mathrm{ng} \mathrm{ml}^{-1}$ for IGF-I. LR3-IGF-I, a recombinant analogue of human IGF-I, was used in preference to the native molecule as it does not interact with IGF binding proteins.

\section{Immunoassays}

Cell-conditioned media were assayed for inhibin A and inhibin B concentrations by specific two-site ELISAs that use monoclonal antibodies raised against synthetic peptide fragments of the human $\alpha-, \beta_{A^{-}}$and $\beta_{B}$-subunits (Muttukrishna et al., 1994; Groome et al., 1996). These assays have been validated previously for domestic fowl as described by Lovell et al. (1998, 2000b). Recombinant human inhibin A and inhibin $B$ were used as assay standards. The detection limits of the inhibin A and inhibin B ELISAs were 2 and $15 \mathrm{pg} \mathrm{ml}^{-1}$, respectively. The recoveries of known amounts of exogenous inhibin A or inhibin B standard were quantitative (94-108\%). Intra- and inter-plate coefficients of variation were $<10 \%$. Progesterone was determined by direct radioimmunoassay as described by Wrathall and Knight (1995). The total cellular DNA content of each well at the end of the culture was determined by fluorimetric assay (Labarca and Paigen, 1980), allowing hormone secretion to be expressed on a per $\mu \mathrm{g}$ DNA basis, thereby normalizing for cell number.

\section{Statistical analysis}

ANOVA was used to evaluate the effects of single and combined treatments on hormone secretion and DNA content, and to make comparisons between cells from F1, F2 and F3 follicles. Hormone release data for each of the three successive periods of culture were analysed separately. In a given culture experiment, treatments were tested using triplicate wells and each experiment was repeated in three independent cultures. Values are mean \pm SEM based on three independent cultures.

\section{Results}

The viability of freshly dispersed cells was always $>90 \%$. Cells were cultured for a maximum of 4 days $(24 \mathrm{~h}$ plating plus $72 \mathrm{~h}$ treatment) and hormone concentrations were determined in conditioned media samples corresponding to 24-48 h, 48-72 h and 72-96 h of culture, hereafter referred to as treatment days 1,2 and 3, respectively. Concentrations of inhibin A and progesterone in conditioned media were easily measurable throughout the study; concentrations of inhibin B were below the assay detection limit.

\section{Basal secretion of inhibin $A$ and progesterone from $F 1$ to F3 granulosa cells}

Basal secretion of both inhibin A and progesterone in F1, F2 and F3 cultures decreased significantly $(P<0.05)$ 
(a)

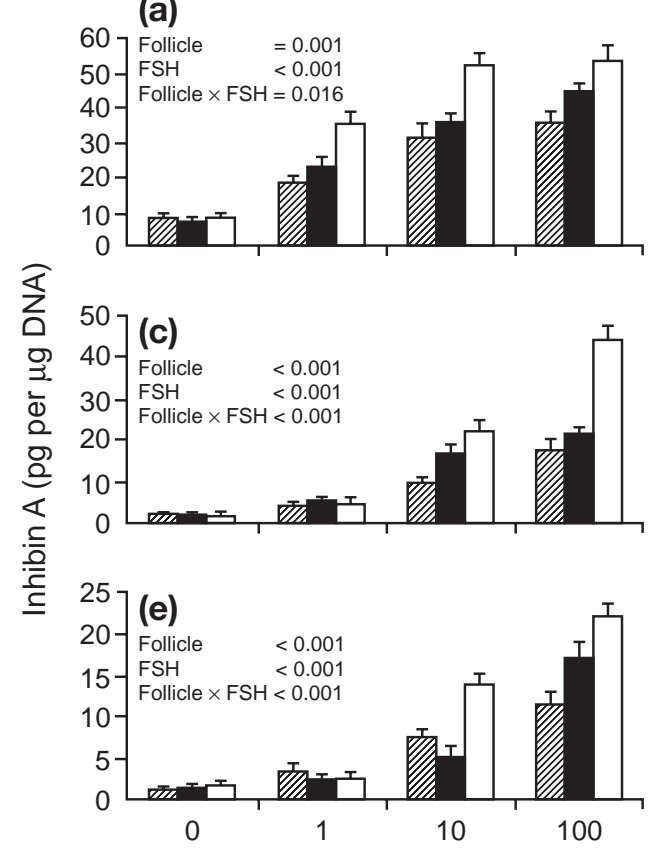

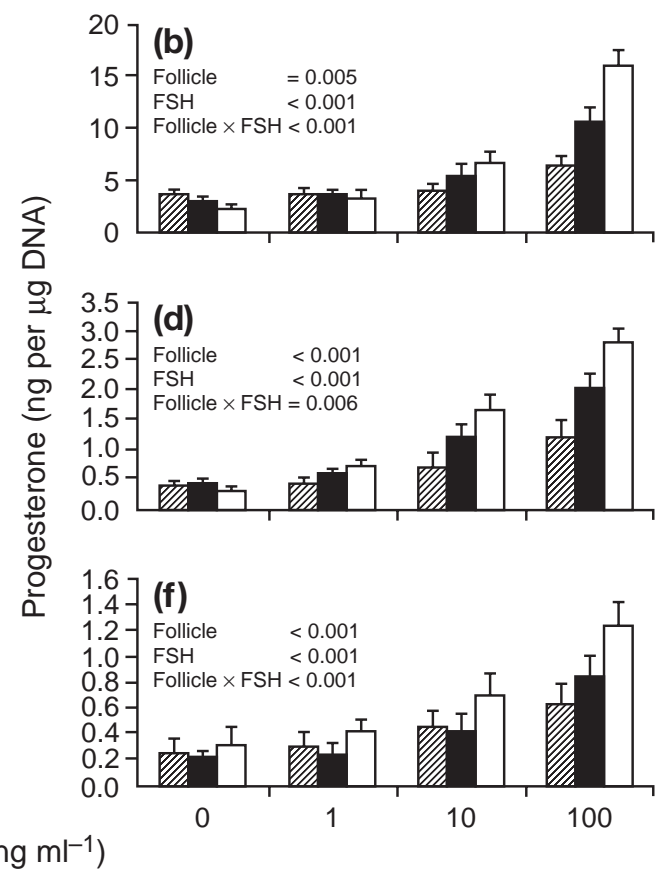

Fig. 2. Effect of $F S H$ on the secretion of $(a, c, e)$ inhibin $A$ and $(b, d, f)$ progesterone by cultured hen granulosa cells derived from F1 $(\mathbb{Z})$, F2 $(\square)$ and F3 $(\square)$ preovulatory follicles. Data for three consecutive $24 \mathrm{~h}$ incubations are shown: (a,b): 24-48 h; (c,d) 48-72 h; and (e,f): 72-96 h. Values are mean $\pm \operatorname{SEM}(n=3$ replicate cultures). Results of ANOVA are indicated on each panel.

between day 1 and day 2 of culture, and remained low during the final day of culture (Fig. 1). A comparable decrease was observed in residual cellular content of inhibin A (data not shown).

\section{Effect of $\mathrm{LH}$ on inhibin A and progesterone secretion from F1 to F3 granulosa cells}

Treatment with LH elicited significant dose-dependent increases $(P<0.001)$ in inhibin A secretion in F1-F3 granulosa cell cultures (Fig. 1a). The magnitude of the response, relative to basal inhibin A secretion, increased progressively over the 3 days of treatment (approximate fourfold increase on day 1 compared with approximate 15 -fold increase on day 3). Two-way ANOVA of results for each day of treatment showed a significant $(P<0.05)$ effect of follicle position on inhibin A secretion: $\mathrm{LH}$-induced inhibin A secretion was slightly higher from F3 granulosa cells than from F1 granulosa cells.

LH treatment also elicited marked dose-dependent increases in progesterone secretion in F1-F3 granulosa cell cultures, with the magnitude of the response increasing over time in culture (approximate sixfold increase on day 1 compared with approximate 15 -fold increase on day 3 ) (Fig. 1b). In contrast to inhibin A secretion, LH-induced progesterone secretion tended to be higher in F1 than in F2 and F3 granulosa cells (only significant on day 1).

\section{Effect of FSH on inhibin A and progesterone secretion from F1 to F3 granulosa cells}

As with $\mathrm{LH}$, treatment with FSH elicited significant dosedependent increases $(P<0.001)$ in inhibin $A$ secretion in F1-F3 granulosa cell cultures (Fig. 2a). The magnitude of the response, relative to basal inhibin A secretion, increased progressively over the 3 days of treatment (approximate fourfold increase on day 1 compared with approximate 12 -fold increase on day 3). Two-way ANOVA of results for each day of treatment showed a highly significant $(P<0.0001)$ effect of follicle position on inhibin A secretion and a significant follicle position $\times \mathrm{FSH}$ treatment interaction $(P<0.05)$ : $F S H$-induced inhibin $A$ secretion was highest from F3 granulosa cells, intermediate from F2 cells and lowest from F1 cells.

FSH treatment also promoted dose-dependent increases in progesterone secretion in F1-F3 granulosa cell cultures (Fig. $2 \mathrm{~b})$. Relative to basal secretion, the magnitude of the response was less than for inhibin A and only increased slightly over the 3 days of treatment. However, two-way ANOVA of results for each day of treatment showed a significant $(P<0.005)$ effect of follicle position on progesterone secretion and a significant follicle position $\times \mathrm{FSH}$ treatment interaction $(P<0.01)$. As observed for inhibin A secretion, $\mathrm{FSH}$-induced progesterone secretion was inversely related to follicle position, being highest from F3 granulosa cells. 


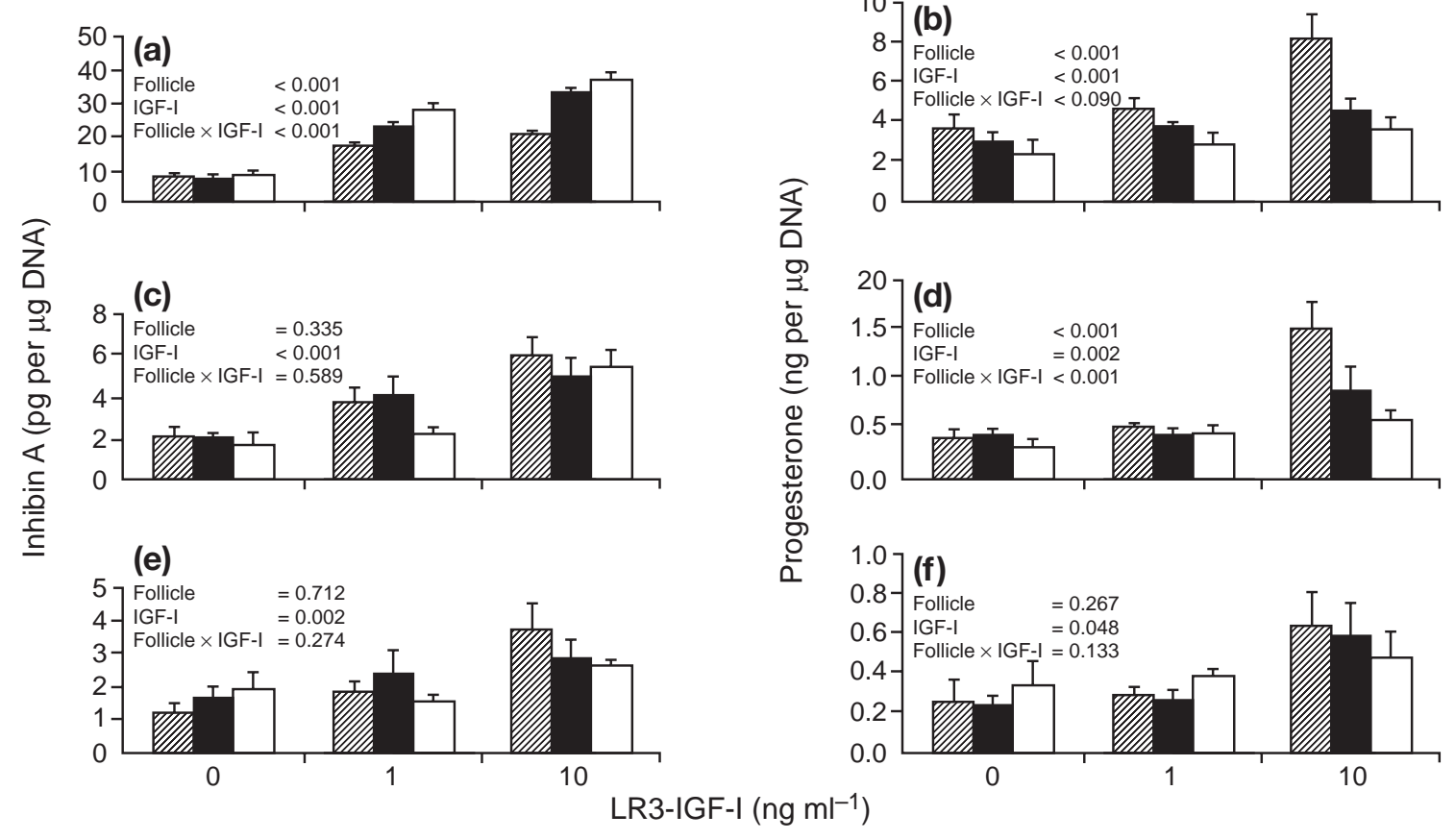

Fig. 3. Effect of long R3 insulin-like growth factor I (LR3-IGF-I) on the secretion of $(a, c, e)$ inhibin A and (b,d,f)

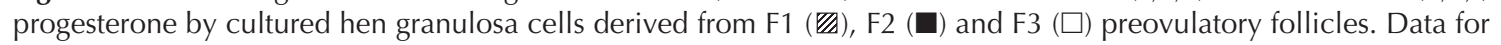
three consecutive $24 \mathrm{~h}$ incubations are shown: (a,b): 24-48 h; (c,d) 48-72 h; and (e,f): 72-96 h. Values are mean \pm $\operatorname{SEM}(n=3$ replicate cultures). Results of ANOVA are indicated on each panel.

\section{Relationship between secreted and cellular inhibin A contents}

A selection of matched conditioned media and cell lysate samples from F1, F2 and F3 granulosa cell cultures terminated after 1,2 and 3 days of treatment $( \pm \mathrm{LH}$ or $\mathrm{FSH})$, were analysed for inhibin A. A significant positive relationship $(r=0.805, P<0.001)$ was observed between secreted (y) and cellular $(x)$ inhibin A content (relative to DNA), as represented by the following regression equation: $y=14.419 x+0.003$. Residual cellular content of inhibin A represented $<10 \%$ of the total inhibin $A$ present in each well.

\section{Effects of LR3-IGF-I analogue on inhibin A and progesterone secretion from $\mathrm{F} 1$ to $\mathrm{F} 3$ granulosa cells}

Considering the results for all three follicle classes, treatment with IGF-I only significantly $(P<0.005)$ enhanced inhibin A secretion during all three culture periods, although the response was most significant on day 1 of treatment (Fig. 3a). Two-way ANOVA of day 1 data showed a significant $(P<0.001)$ effect of follicle position and a significant $(P<0.001)$ follicle class $\times$ IGF-I treatment interaction, with cells from the F3 follicle being most responsive to IGF-I and cells from $\mathrm{F} 1$ follicles being least responsive. This difference was not apparent on days 2 and 3 of treatment.

Overall, IGF-I had a modest stimulatory effect on progesterone secretion at all three time points (Fig. 3b). In contrast to inhibin A secretion, IGF-I-induced progesterone secretion was highest from F1 granulosa cells, with F3 granulosa cells showing little or no response at any time point.

Modulatory effect of LR3-IGF-I analogue on LH-induced secretion of inhibin A and progesterone from F1 to F3 granulosa cells

Co-treatment with IGF-I resulted in a significant timedependent enhancement of $\mathrm{LH}$-induced inhibin $\mathrm{A}$ secretion that became clearly evident during days 2 and 3 of treatment (Fig. 4a). During day 1 of treatment, the inhibin A response to co-treatment ranged from being approximately additive (in $\mathrm{F} 1$ cells) to being no different from the responses to either factor alone (in F3 cells). This difference in responsiveness of F1, F2 and F3 cells is supported by the ANOVA, which indicated a significant effect of follicle position, as well as significant follicle position $\times$ treatment interactions. On days 2 and 3 of treatment, a synergistic effect of IGF-I on LH-induced inhibin A secretion was clearly evident. Relative to the inhibin A response elicited by $10 \mathrm{ng} \mathrm{LH} \mathrm{ml}^{-1}$ only, co-treatment with $10 \mathrm{ng}$ IGF-I ml-1 promoted a further three- to fourfold increase $(P<0.001)$ on both days. However, the response was not uniform among cells from different follicle positions: in relative terms, F2 cells showed a greater response to co-treatment than did either $\mathrm{F} 1$ or $\mathrm{F} 3$ cells, this difference being most marked on day 3 $(P<0.0001)$. 


\section{(a)}
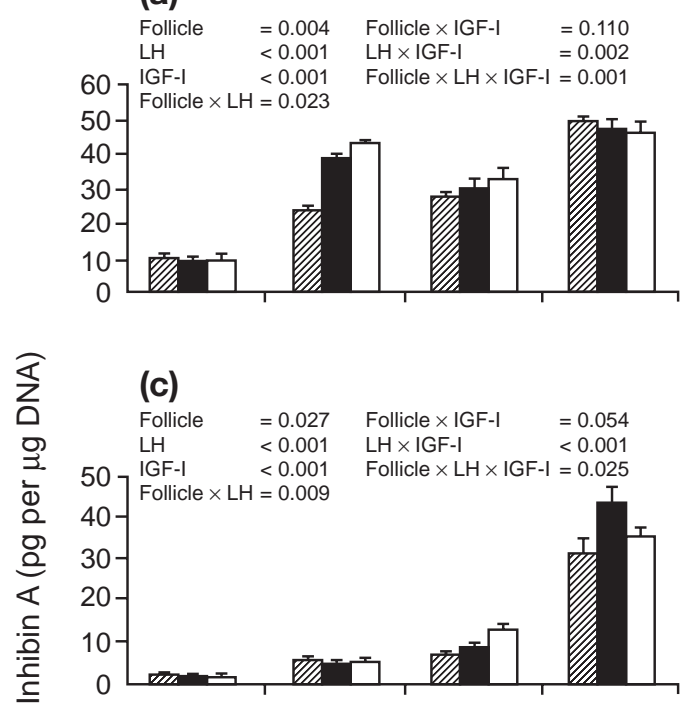

\section{(e)}

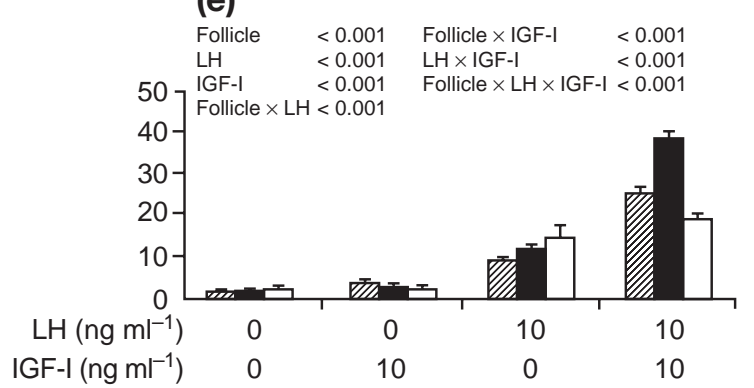

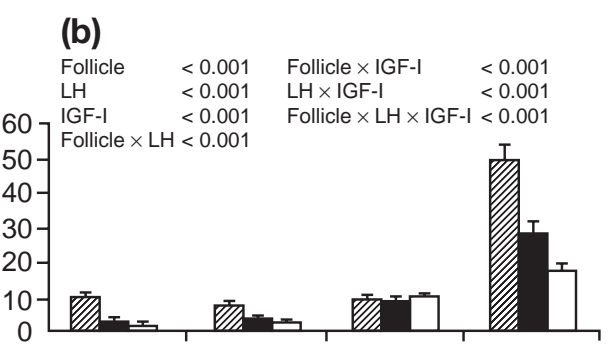

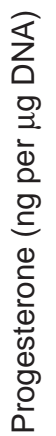

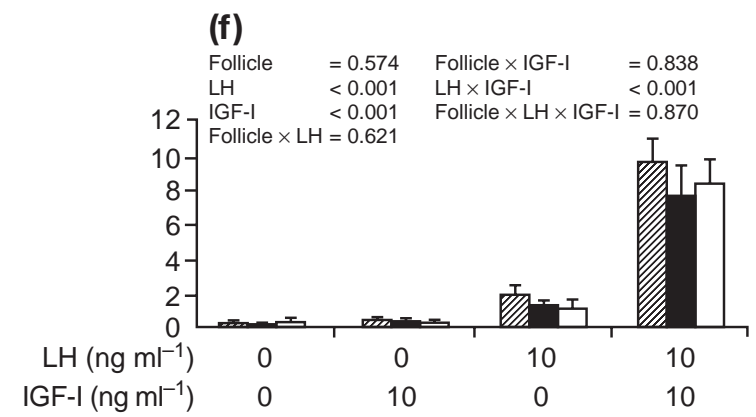

Fig. 4. Effects of LH and long R3 insulin-like growth factor I (LR3-IGF-I), alone and in combination, on the secretion of $(\mathrm{a}, \mathrm{c}, \mathrm{e})$ inhibin $\mathrm{A}$ and $(\mathrm{b}, \mathrm{d}, \mathrm{f})$ progesterone by cultured hen granulosa cells derived from $\mathrm{F} 1(\mathbb{\mathbb { Z }}), \mathrm{F} 2(\boldsymbol{\square})$ and $\mathrm{F} 3(\square)$ preovulatory follicles. Data for three consecutive $24 \mathrm{~h}$ incubations are shown: (a,b): 24-48 h; (c,d) 48-72 h; and (e,f): 72-96 h. Values are mean $\pm \operatorname{SEM}(n=3$ replicate cultures). Results of ANOVA are indicated on each panel.

Co-treatment with IGF-I also enhanced LH-induced progesterone secretion but, in contrast to inhibin A secretion, a marked synergistic effect was evident in $\mathrm{F} 1$ cells from day 1 of treatment onwards (fivefold enhancement of $\mathrm{LH}$ induced progesterone secretion; $P<0.001)$. This response to IGF-I was much lower in F2 cells and absent in F3 cells (ANOVA: follicle position $\times \mathrm{LH} \times \mathrm{IGF}-\mathrm{I}$ interaction, $P<0.001$ ). On days 2 and 3, IGF-I also had a marked synergistic effect on $\mathrm{LH}$-induced progesterone secretion (ANOVA: LH $\times$ IGF-I interaction, $P<0.001$ ); similar enhancement was observed for all three follicle positions (ANOVA: follicle position $\times \mathrm{LH} \times \mathrm{IGF}-\mathrm{I}$ interaction, not significant).

Modulatory effect of LR3-IGF-I analogue on FSHinduced secretion of inhibin $A$ and progesterone from $F 1$ to F3 granulosa cells

Co-treatment with IGF-I also enhanced FSH-induced inhibin A secretion in a time- and follicle-dependent way (Fig. 5a). During day 1 of treatment, the response to the two factors was additive in F1 and F2 granulosa cells but much less than additive in $\mathrm{F} 3$ cells. On days 2 and 3, a clear synergistic effect of IGF-I on FSH-induced inhibin A secretion was evident in $\mathrm{F} 3$ granulosa cells (approximate threefold enhancement relative to FSH only, $P<0.001$ ) but not in F1 granulosa cells, in which the response to both treatments was barely additive (ANOVA: follicle position $\times$ FSH $\times$ IGF-I treatment interaction, $P<0.001$ ).

Overall, co-treatment with IGF-I did not significantly modify FSH-induced progesterone secretion during day 1 or 2 of treatment (ANOVA: FSH $\times$ IGF-I treatment interaction, not significant on either day). However, IGF-I tended to enhance FSH-induced progesterone secretion in F3 granulosa cells and this effect was significant by day 3 of treatment (approximate threefold enhancement, $P<0.001$ ).

\section{Effect of gonadotrophins and LR3-IGF-I analogue on cell proliferation}

Treatment of cells from F1, F2 and F3 follicles with either $\mathrm{LH}$ or FSH alone had no effect on number of cells, as 
(a)
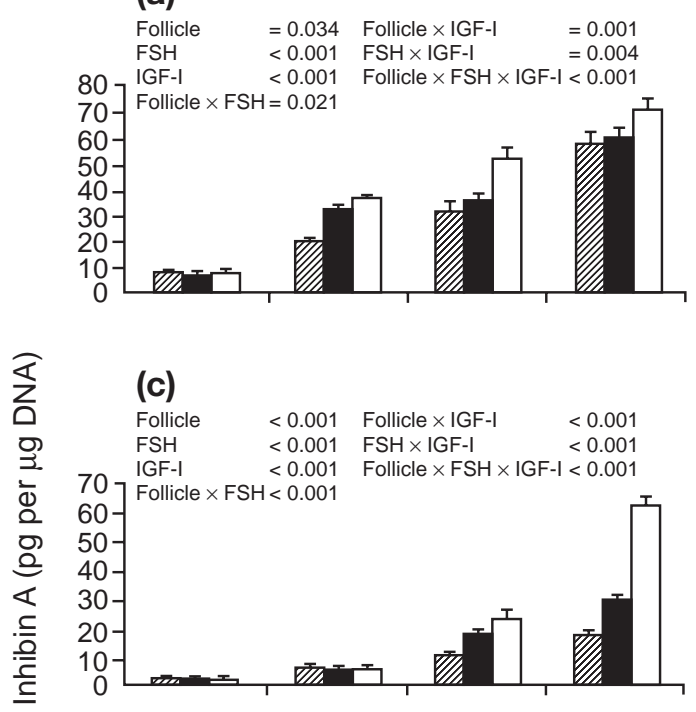

(e)

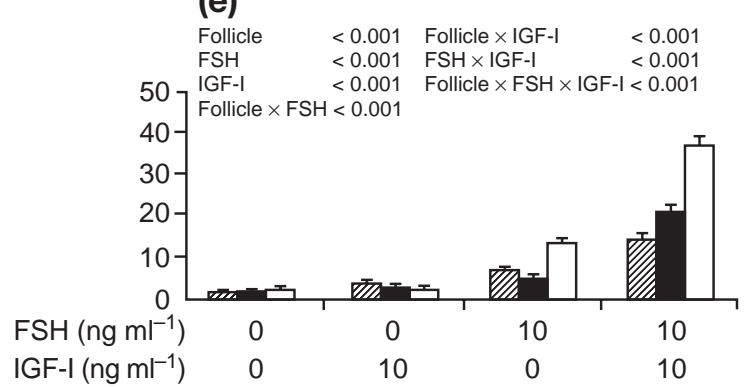

\section{(b)}

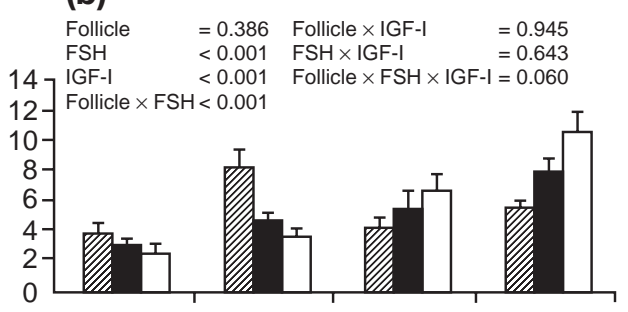

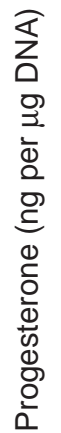

\section{(d)}

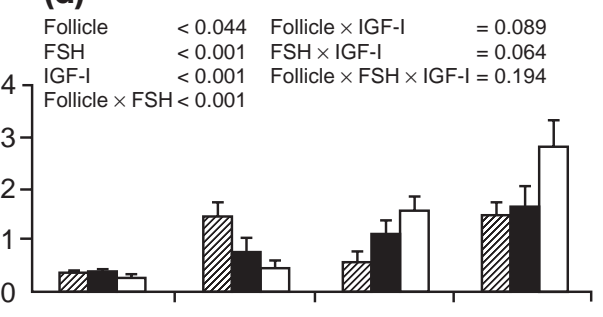

(f)

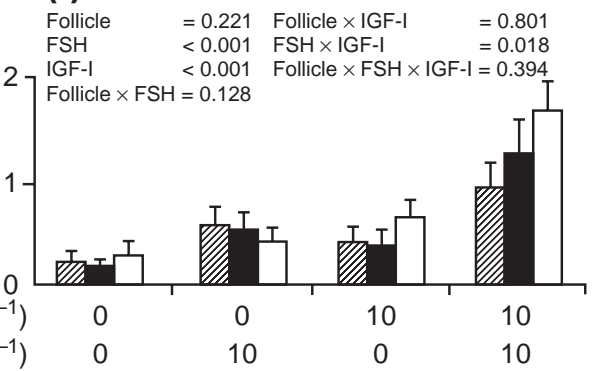

Fig. 5. Effects of FSH and long R3 insulin-like growth factor I (LR3-IGF-I), alone and in combination, on the secretion of

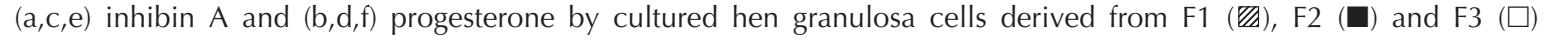
preovulatory follicles. Data for three consecutive $24 \mathrm{~h}$ incubations are shown: (a,b): 24-48 h; (c,d) 48-72 h; and (e,f): 72-96 h. Values are mean \pm SEM ( $n=3$ replicate cultures). Results of ANOVA are indicated on each panel.

reflected by cellular DNA content measured at the end of the culture period. In contrast, LR3-IGF-I either alone, or in the presence of $\mathrm{LH}$ or $\mathrm{FSH}$, promoted a small but significant increase in DNA content (approximate 25\% increase, $P<0.001)$ in cells from all three follicle classes (data not shown).

\section{Discussion}

To our knowledge, this study is the first to attempt to quantify the secretion of specific inhibin dimers (inhibins A and B) from cultured avian granulosa cells and to relate this to steroid (progesterone) secretion. Unfortunately, it was only possible to measure inhibin $A$ and progesterone secretion, as inhibin B concentrations in cell-conditioned media were below the detection limits of the assay. The main findings were: (i) under basal conditions, granulosa cells from F1, F2 and F3 preovulatory follicles secreted similar amounts of inhibin A throughout the culture period; (ii) inhibin A secretion was responsive to stimulation by both $\mathrm{LH}$ and FSH in a time- and follicle-dependent way; (iii) inhibin A secretion was positively correlated with residual cellular inhibin A content; and (iv) IGF-I stimulated inhibin A secretion and enhanced the secretory response to both $\mathrm{LH}$ and FSH in a time- and follicle-dependent way.

In general, the differences in basal and gonadotrophininduced progesterone secretion by F1, F2 and F3 granulosa cells observed in the present study are in accordance with previous reports (Hammond et al., 1981; Asem and Hertelendy, 1985; Nakamura et al., 1991; Onagbesan et al., 1999b, 2000). However, inter-follicle differences in basal and $\mathrm{LH}$-induced progesterone secretion were less pronounced than in other studies and were confined to day 1 of treatment. This difference is probably because the hens were killed about $4 \mathrm{~h}$ after ovulation of the previous F1 follicle in the present study, rather than about $12 \mathrm{~h}$ after ovulation as reported in most other studies. Thus, the F1 follicles from which granulosa cells were harvested in the present study had only recently acquired F1 status. This time point was selected on the basis of our previous finding (Lovell et al., 1998) that the ex vivo tissue content of inhibin $\mathrm{A}$ in the $\mathrm{F} 1$ granulosa layer was already some 20 -fold higher 
than in the corresponding F2 granulosa layer at this time. Given this, it was surprising to find that granulosa cells isolated from F1, F2 and F3 follicles secreted similar amounts of inhibin A after 2, 3 or 4 days of in vitro culture; moreover, residual cellular contents of inhibin A after 4 days of culture were similar in F1, F2 and F3 granulosa cells. These apparent discrepancies between ex vivo tissue contents of inhibin A (Lovell et al., 1998) and in vivo rates of inhibin A secretion or cell content, as measured in the present study, presumably reflect the failure of the culture system to reproduce adequately the environment under which granulosa cells operate in vivo. In particular, the fact that the granulosa cells are deprived of paracrine factors arising from the surrounding theca layer (such as IGF-I and activin) may perturb their function in vitro.

Nonetheless, differential inhibin $A$ and progesterone responses to gonadotrophins were evident between follicle categories, with F3 granulosa cells being more sensitive to $\mathrm{FSH}$ than were F1 granulosa cells; conversely, F1 granulosa cells were generally more sensitive to $\mathrm{LH}$ than were F3 granulosa cells. A decrease in $\mathrm{FSH}$ responsiveness as follicles move up the preovulatory hierarchy is consistent with previous observations: You et al. (1996) reported a significant reduction in expression of $\mathrm{FSH}$ receptor mRNA in granulosa cells from F3 to F1 follicles, which corresponded to a decreased FSH receptor binding, without a change in receptor affinity (Ritzhaupt and Bahr, 1987). Calvo and Bahr (1983) also found higher FSH-stimulated adenylyl cyclase activity in granulosa cells from smaller preovulatory follicles.

Although LH-stimulated progesterone secretion during the day 1 of treatment increased during follicular development $(\mathrm{F} 1>\mathrm{F} 2>\mathrm{F} 3)$ there was no significant difference between $\mathrm{F} 1$ and $\mathrm{F} 3$ granulosa cells in LH-stimulated inhibin A secretion at this time. Granulosa cell LH receptor mRNA expression is similar in F3 to F1 follicles (Johnson et al., 1996). Moreover, at the stage of the ovulatory cycle at which granulosa cells were collected in the present study (approximately $4 \mathrm{~h}$ after ovulation of the previous F1 follicle), Calvo et al. (1981) found no inter-follicle difference in basal and LH-stimulated granulosa cell adenylyl cyclase activity; increased responsiveness of the adenylyl cyclase system to LH was not demonstrated in the F1 and F2 granulosa layers until $12 \mathrm{~h}$ before the expected time of ovulation of the F1 follicle (some $8 \mathrm{~h}$ later than the time of follicle collection in the present study). Consistent with our findings, Davis et al. (1999) reported that both $\mathrm{LH}$ and FSH increase expression of inhibin- $\alpha$ subunit mRNA and inhibin- $\alpha$ protein by cultured hen granulosa cells. These authors also noted a requirement for gonadotrophin to maintain expression of inhibin- $\alpha$ mRNA in vitro, with concentrations decreasing to barely detectable values after $24-48 \mathrm{~h}$ of culture in the absence of $\mathrm{LH}$ or FSH. This requirement is in accordance with our observation of a significant reduction in basal inhibin A secretion from F1, F2 and F3 granulosa cell cultures after $48 \mathrm{~h}$ of culture. A comparable decrease in residual cell content of inhibin $A$, consistent with a reduced rate of inhibin- $\alpha$ mRNA expression, translation and posttranslational processing to form dimeric inhibin A, was also observed in the present study. The strong positive correlation between cellular and secreted inhibin A $(r=0.805$, $P<0.001$ ), and the finding that $>90 \%$ of total inhibin $A$ was present in cell-conditioned media, indicate that newly synthesized inhibin A dimer is not stored in significant amounts but is secreted rapidly.

Although Davis et al. (1999) demonstrated that gonadotrophins increase mRNA expression and secretion of inhibin$\alpha$ in preovulatory granulosa cells, Chen and Johnson (1996a) estimated expression of F1 granulosa $\alpha$-subunit mRNA to be seven-times higher than for the corresponding $\beta_{A^{-}}$subunit. It has also been shown that F1 preovulatory follicles (Lovell et al., 1998) and hen plasma (Lovell et al., $2000 a, 2001)$ contain an excess of inhibin- $\alpha$ compared with dimeric inhibin $A$. These observations indicate that $\beta_{A^{-}}$subunit expression or production may be a key factor controlling inhibin A production. In support of this view, Chen and Johnson (1996b) found that administration of a large dose of $\mathrm{LH}$ to laying hens (to mimic the preovulatory LH surge) reduced expression of $\beta_{\mathrm{A}}$-subunit mRNA in $\mathrm{F} 1$ granulosa cells, although it did not alter expression of inhibin- $\alpha$ mRNA. Moreover, during the hen ovulatory cycle, plasma inhibin A reached a maximum at the time of the $\mathrm{LH}$ surge and, thereafter, concentrations were reduced (Lovell et al., 2000a).

Secretion of dimeric inhibins has recently been investigated in rat (Lanuza et al., 1999) and bovine (Boudjemaa et al., 2000; Glister et al., 2001) granulosa cells, human granulosa-lutein cells (Vanttinen et al., 2000) and mouse preantral follicles (Smitz and Cortvrindt, 1999). Increased expression of inhibin/activin $\alpha$ - and $\beta_{A^{-}}$-subunit mRNA in mammals has been demonstrated in response to FSH (Su and Hsueh, 1994) or CAMP analogues (Tuuri et al., 1996). Although both genes were simulated by CAMP, expression of inhibin- $\alpha$ mRNA was stimulated preferentially at low CAMP concentration, whereas expression of inhibin/activin $\beta_{A}$-subunit mRNA required a high cAMP concentration. Expression of inhibin/activin $\beta_{A^{-}}$subunit gene was also enhanced more rapidly (approximately $3 \mathrm{~h}$ ) than expression of inhibin- $\alpha$ (24-48 h) (Tuuri et al., 1996). Mammalian granulosa cells, like avian granulosa cells, synthesize excess inhibin- $\alpha$ (Bicsak et al., 1988; Knight et al., 1989, 1991; Lovell et al., 1998); however, all the monomeric inhibin- $\alpha$ forms isolated to date lack classical inhibin-like activity, as they do not have a suppressive effect on pituitary FSH secretion. Schneyer et al. (1991) demonstrated that full-length inhibin- $\alpha$ precursors can compete with $\mathrm{FSH}$ for $\mathrm{FSH}$ receptor binding. Therefore, the possibility of an autocrine or paracrine action of endogenous inhibin- $\alpha$ precursor in modulating granulosa cell responsiveness to FSH during these in vitro studies cannot be eliminated.

IGF-I and IGF-II are both expressed in the ovary of domestic hens (Roberts et al., 1994; Armstrong and Hogg, 1996). Theca expression of IGF-I mRNA increased during 
follicular development from follicles 2-6 $\mathrm{mm}$ in diameter to the F1 stage, whereas granulosa expression of IGF-I mRNA could not be detected (Armstrong and Hogg, 1996). As expression of IGF receptor mRNA has also been reported in preovulatory follicle granulosa cells (Armstrong and Hogg, 1996), we investigated the putative role of IGF-I in regulating basal and gonadotrophin-induced inhibin A and progesterone secretion by granulosa cells.

In the present study, IGF-I analogue enhanced basal, LHand $\mathrm{FSH}$-stimulated inhibin $\mathrm{A}$ and progesterone secretion in a follicle position- (F1-F3) and time-dependent way. The magnitude of IGF-I enhancement of LH-stimulated progesterone and inhibin A secretion during the first $24 \mathrm{~h}$ of treatment was greater for F1 follicles than for F3 follicles, indicating that, in F1 follicles, theca-derived IGF-I may exert a paracrine action to sensitize granulosa cells to $\mathrm{LH}$ and, thus, maximize secretion of progesterone and inhibin $A$ at about the time of the preovulatory LH surge. In this context, Lovell et al. (2000a) reported maximum inhibin A concentrations in peripheral blood of hens coincident with the preovulatory LH and progesterone increase. IGF-I also enhanced $\mathrm{FSH}$-stimulated secretion of inhibin A by granulosa cells; however, in absolute terms, inhibin A secretion was significantly higher for F3 than for F1 granulosa cells. This presumably reflects a decrease in FSH sensitivity as follicle maturation proceeds, as IGF enhancement of FSHinduced progesterone secretion was also highest for $\mathrm{F} 3$ cells and lowest for F1 cells. Comparable effects of $\mathrm{LH}, \mathrm{FSH}$ and IGF-I on progesterone secretion have been reported previously in cultures of granulosa cells from hen preovulatory follicles (Onagbesan and Peddie, 1995; Onagbesan et al., $1999 b, 2000)$ but the present study is the first in which these observations have been extended to inhibin A secretion. A modulatory action of IGF-I on basal and FSH-stimulated immunoreactive inhibin and steroid secretion has been documented in rat (Bicsak et al., 1986), pig (Michel et al., 1991) and bovine (Glister et al., 2001) granulosa cell cultures.

In conclusion, as in mammals, inhibin A secretion by ovarian granulosa cells of hens is regulated by a combination of endocrine and paracrine/autocrine factors. Our findings support a positive role for theca-derived IGF-I acting both alone, and in combination with $\mathrm{LH}$ and $\mathrm{FSH}$, to upregulate granulosa cell steroidogenesis and inhibin A production by preovulatory follicles.

The authors would like to thank S. A. Feist for skilled technical assistance, A. Parlow (NHPP) for supplying purified ovine $\mathrm{LH}$ and $\mathrm{FSH}$, and BBSRC for financial support (grant number 45/S11514).

\section{References}

Adashi EY, Resnick CE, Ricciarelli E et al. (1992) Granulosa cell-derived insulin-like growth factor (IGF) binding proteins are inhibitory to IGF-I hormonal action. Evidence derived from the use of a truncated IGF-I analogue Journal of Clinical Investigation 90 1593-1599

Armstrong DG and Hogg CO (1996) Insulin-like growth factor I (IGF-I), IGFII and type-I IGF receptor gene expression in the ovary of the laying hen Journal of Reproduction and Fertility 106 101-106
Asem EK and Hertelendy F (1985) Influence of follicular maturation on luteinizing hormone-, cyclic $3^{\prime}, 5^{\prime}$-adenosine monophosphate-, forskolin- and cholesterol-stimulated progesterone production in hen granulosa cells Biology of Reproduction 32 257-268

Bicsak TA, Tucker EM, Cappel S, Vaughan J, Rivier J, Vale W and Hsueh AJ (1986) Hormonal regulation of granulosa cell inhibin biosynthesis Endocrinology 119 2711-2719

Bicsak TA, Cajander SB, Vale W and Hsueh AJW (1988) Inhibin: studies of stored and secreted forms by biosynthetic labeling and immunodetection in cultured rat granulosa cells Endocrinology 122 741-748

Boudjemaa ML, Rouillier P, Bhatia B, Silva JM, Guilbault LA and Price CA (2000) Effect of FSH and cell localization on dimeric inhibin A secretion from bovine granulosa cells in culture Journal of Endocrinology 165 207-215

Calvo FO and Bahr JM (1983) Adenylyl cyclase system of the small preovulatory follicles of the domestic hen: responsiveness to folliclestimulating hormone and luteinizing hormone Biology of Reproduction 29 542-547

Calvo FO, Wang SC and Bahr JM (1981) LH-stimulatable adenylyl cyclase activity during the ovulatory cycle in granulosa cells of the three largest follicles and the postovulatory follicle of the domestic hen (Gallus domesticus). Biology of Reproduction 25 805-812

Chen C-C and Johnson PA (1996a) Molecular cloning of inhibin/activin $\beta_{A}$ subunit complementary deoxyribonucleic acid and expression of inhibin/activin $\alpha$ and $\beta_{\mathrm{A}}$-subunits in the domestic hen Biology of Reproduction 54 429-435

Chen CC and Johnson PA (1996b) LH decreases mRNA for inhibin/activin $\beta_{A}$-subunit in the largest preovulatory follicle of the hen Biology of Reproduction Supplement 52157 (Abstract 403)

Davis AJ, Brooks CF and Johnson PA (1999) Gonadotropin regulation of inhibin $\alpha$-subunit mRNA and immunoreactive protein in cultured chicken granulosa cells General and Comparative Endocrinology 116 90-113

Etches RJ and Duke CE (1984) Progesterone, androstenedione and oestradiol content of theca and granulosa tissue of the four largest ovarian follicles during the ovulatory cycle of the hen (Gallus domesticus). Journal of Endocrinology 103 71-76

Gilbert AB, Evans AJ, Perry MM and Davidson MH (1977) A method for separating the granulosa cells, the basal lamina and the theca of the preovulatory ovarian follicle of the domestic fowl (Gallus domesticus). Journal of Reproduction and Fertility 50 179-181

Glister C, Tannetta DS, Groome NP and Knight PG (2001) Interactions between follicle-stimulating hormone and growth factors in modulating secretion of steroids and inhibin-related peptides by non-luteinized bovine granulosa cells Biology of Reproduction 65 1200-1208

Groome NP, Illingworth PJ, O'Brien M, Pai R, Rodger FE, Mather JP and McNeilly AS (1996) Measurement of dimeric inhibin B throughout the human menstrual cycle Journal of Clinical Endocrinology and Metabolism 81 1404-1405

Hammond RW, Burke WH and Hertelendy F (1981) Influence of follicular maturation on progesterone release in chicken granulosa cells in response to turkey and ovine gonadotropins Biology of Reproduction 24 1048-1055

Hsueh AJ, Welsh TH and Jones PB (1981) Inhibition of ovarian and testicular steroidogenesis by epidermal growth factor Endocrinology 108 2002-2004

Johnson AL, Bridgham JT and Wagner B (1996) Characterization of a chicken luteinizing hormone receptor (cLH-R) complementary deoxyribonucleic acid, and expression of $\mathrm{CLH}-\mathrm{R}$ messenger ribonucleic acid in the ovary Biology of Reproduction 55 304-309

Kato M, Shimada K, Saito N, Noda K and Ohta M (1995) Expression of progesterone $5017 \alpha$-hydroxylase and progesterone 50 aromatase genes in isolated granulosa, theca interna, and theca externa layers of chicken ovarian follicles during follicular growth Biology of Reproduction $\mathbf{5 2}$ 405-410

Knight PG and Glister C (2001) Potential local regulatory functions of inhibins, activins and follistatin in the ovary Reproduction 121 503-512

Knight PG, Beard AJ, Wrathall JHM and Castillo RJ (1989) Evidence that the bovine ovary secretes large amounts of monomeric inhibin $\alpha$ subunit 
and its isolation from bovine follicular fluid Journal of Molecular Endocrinology 2 189-200

Knight PG, Groome N and Beard AJ (1991) Development of a two-site immunoradiometric assay for dimeric inhibin using antibodies against chemically synthesized fragments of the $\alpha$ and $\beta$ subunit Journal of Endocrinology 129 R9-R12

Labarca C and Paigen K (1980) A simple, rapid, and sensitive DNA assay procedure Analytical Biochemistry 102 344-352

Lanuza GM, Groome NP, Baranao JL and Campo S (1999) Dimeric inhibin $\mathrm{A}$ and $\mathrm{B}$ production are differentially regulated by hormones and local factors in rat granulosa cells Endocrinology 140 2549-2554

Lovell TM, Gladwell RT, Cunningham FJ, Groome NP and Knight PG (1998) Differential changes in inhibin A, activin A, and total $\alpha$-subunit levels in granulosa and thecal layers of developing preovulatory follicles in the chicken Endocrinology 139 1164-1171

Lovell TM, Vanmontfort D, Bruggeman V, Decuypere E, Groome NP, Knight PG and Gladwell RT (2000a) Circulating concentrations of inhibin-related proteins during the ovulatory cycle of the domestic fowl (Gallus domesticus) and after induced cessation of egg laying Journal of Reproduction and Fertility 119 323-328

Lovell TM, Knight PG, Groome NP and Gladwell RT (2000b) Measurement of dimeric inhibins and effects of active immunization against inhibin $\alpha$ subunit on plasma hormones and testis morphology in the developing cockerel Biology of Reproduction 63 213-221

Lovell TM, Gladwell RT and Knight PG (2000c) Inhibin A, inhibin B, activin $A$ and follistatin in granulosa and theca layers of pre- and posthierarchical ovarian follicles of the domestic fowl (Gallus domesticus). Journal of Reproduction and Fertility Supplement 2618 (Abstract 43)

Lovell TM, Knight PG, Groome NP and Gladwell RT (2001) Changes in plasma inhibin A levels during sexual maturation in the female chicken and the effects of active immunization against inhibin $\alpha$-subunit on reproductive hormone profiles and ovarian function Biology of Reproduction 64 188-196

Michel U, Ludemann S, Jarry H and Wuttke W (1991) Effects of growth factors and hormones on basal and FSH-stimulated inhibin production by porcine granulosa cells in vitro. Reproduction, Fertility and Development 3 201-213

Muttukrishna S, Fowler PA, Groome NP, Mitchell GG, Robertson WR and Knight PG (1994) Serum concentrations of dimeric inhibin during the spontaneous human menstrual cycle and after treatment with exogenous gonadotrophin Human Reproduction 9 1634-1642

Nakamura T, Funabashi $\mathbf{M}$ and Tanabe $\mathbf{Y}$ (1991) In vitro studies on steroidogenesis in the presence of pregnenolone as precursors by the follicular tissue of the domestic fowl (Gallus domesticus). Journal of Steroid Biochemistry and Molecular Biology 38 105-110

Onagbesan OM and Peddie MJ (1995) Effects of insulin-like growth factor I and interactions with transforming growth factor $\alpha$ and $\mathrm{LH}$ on proliferation of chicken granulosa cells and production of progesterone in culture Journal of Reproduction and Fertility 104 259-265

Onagbesan OM, Gullick W, Woolveridge I and Peddie MJ (1994) Immunohistochemical localization of epidermal growth factor receptors, epidermal growth factor-like and transforming growth factor $\alpha$-like peptides in chicken ovarian follicles Journal of Reproduction and Fertility 102 147-153

Onagbesan OM, Vleugels B, Buys N, Bruggeman V, Safi M and Decuypere E (1999a) Insulin-like growth factors in the regulation of avian ovarian functions Domestic Animal Endocrinology 17 299-313

Onagbesan OM, Decuypere E, Leenstra F and Ehlhardt DA (1999b) Differential effects of amount of feeding on cell proliferation and progesterone production in response to gonadotrophins and insulin-like growth factor I by ovarian granulosa cells of broiler breeder chickens selected for fatness or leanness Journal of Reproduction and Fertility 116 73-85

Onagbesan OM, Mast J, Goddeeris B and Decuypere E (2000) Effect of TNF- $\alpha$ on LH and IGF-I modulated chicken granulosa cell proliferation and progesterone production during follicular development Journal of Reproduction and Fertility 120 433-442

Peddie MJ, Onagbesan OM and Williams J (1994) Chicken granulosa cell proliferation and progesterone production in culture: effects of EGF and theca secretions General and Comparative Endocrinology 94 341-356

Porter TE, Hargis BM, Silsby JL and El Halawani ME (1989) Differentia steroid production between theca interna and theca externa cells: a three-cell model for follicular steroidogenesis in avian species Endocrinology 125 109-116

Ritzhaupt LK and Bahr JM (1987) A decrease in FSH receptors of granulosa cells during follicular maturation in the domestic hen Journal of Endocrinology 115 303-310

Roberts RD, Sharp PJ, Burt DW and Goddard C (1994) Insulin-like growth factor-I in the ovary of the laying hen: gene expression and biological actions on granulosa and thecal cells General and Comparative Endocrinology 93 327-336

Safi M, Buys N, Onagbesan OM, Vleugels B and Decuypere E (1998) Quantification of inhibin/activin $\alpha$ and $\beta_{A}$ subunit messenger ribonucleic acid by competitive reverse transcription-polymerase chain reaction in chicken granulosa cells during follicular development Biology of Reproduction 59 1047-1054

Schneyer AL, Sluss PM, Whitcomb RW, Martin KA, Sprengel R and Crowley WF (1991) Precursors of $\alpha$-inhibin modulate follicle-stimulating hormone receptor binding and biological activity Endocrinology 129 1987-1999

Smitz J and Cortvrindt R (1998) Inhibin A and B secretion in mouse preantral follicle culture Human Reproduction 13 927-935

Su JGJ and Hsueh AJW (1994) Activin stimulation of inhibin $\alpha$-gene promoter in cultured rat granulosa cells Endocrine 2 715-721

Tuuri T, Erämaa M, van Schaik RHN and Ritvos O (1996) Differentia regulation of inhibin/activin $\alpha$ - and $\beta_{\mathrm{A}}$-subunit and follistatin mRNAs by CAMP and phorbol ester in cultured human granulosa-luteal cells Molecular and Cellular Endocrinology 121 1-10

Vanmontfort D, Rombauts L, Decuypere E and Verhoeven G (1992) Source of immunoreactive inhibin in the chicken ovary Biology of Reproduction 47 977-983

Vanttinen T, Liu J, Hyden-Granskog C, Parviainen M, Penttila I, Voutilainen R and Voutilainen R (2000) Regulation of immunoreactive inhibin $A$ and $B$ secretion in cultured human granulosa-luteal cells by gonadotropins, activin A and insulin-like growth factor type-1 receptor Journal of Endocrinology $167289-294$

Wrathall JH and Knight PG (1995) Effects of inhibin-related peptides and oestradiol on androstenedione and progesterone secretion by bovine theca cells in vitro. Journal of Endocrinology 145 491-500

Xiao S, Robertson DM and Findlay JK (1992) Effects of activin and folliclestimulating hormone (FSH)-suppressing protein/follistatin on $\mathrm{FSH}$ receptors and differentiation of cultured rat granulosa cells Endocrinology 131 1009-1016

You S, Bridgham JT, Foster DN and Johnson AL (1996) Characterization of the chicken follicle-stimulating hormone receptor (cFSH-R) complementary deoxyribonucleic acid, and expression of cFSH-R messenger ribonucleic acid in the ovary Biology of Reproduction 55 1055-1062

Received 10 August 2001.

First decision 12 October 2001.

Accepted 7 November 2001 